University of Nebraska - Lincoln

DigitalCommons@University of Nebraska - Lincoln

Faculty Publications, Classics and Religious

Studies Department

April 2005

\title{
Reading Deuteronomy in the Second Temple Period
}

Sidnie White Crawford

University of Nebraska-Lincoln, scrawford1@unl.edu

Follow this and additional works at: https://digitalcommons.unl.edu/classicsfacpub

Part of the Classics Commons

Crawford, Sidnie White, "Reading Deuteronomy in the Second Temple Period" (2005). Faculty Publications, Classics and Religious Studies Department. 22.

https://digitalcommons.unl.edu/classicsfacpub/22

This Article is brought to you for free and open access by the Classics and Religious Studies at DigitalCommons@University of Nebraska - Lincoln. It has been accepted for inclusion in Faculty Publications, Classics and Religious Studies Department by an authorized administrator of DigitalCommons@University of Nebraska - Lincoln. 


\title{
Reading Deuteronomy in the Second Temple Period
}

\author{
Sidnie White Crawford
}

\section{INTRODUCTION}

The book of Deuteronomy was one of the most popular religious texts in the Second Temple period. The finds from the Judean Desert present us with a wealth of manuscripts of Deuteronomy from the late Second Temple period, and the literature of Second Temple Judaism attests to the importance of Deuteronomy in Jewish thought in the period, quoting, alluding, and reusing the text in numerous ways. In this paper I will present at least some of the evidence for the popularity of Deuteronomy through a look at some of the texts found in the caves at Qumran. I will begin with manuscripts of Deuteronomy itself, next I will turn to a group of texts that uses portions of Deuteronomy for liturgical or study purposes (including the phylacteries and the mezuzot), and finally I will examine two texts from the category "Rewritten Bible" that utilize Deuteronomy, 4QReworked Pentateuch and the Temple Scroll.

\section{The Popularity of Deuteronomy}

Deuteronomy is well represented in the Qumran caves, second only to the book of Psalms in the number of copies. The total number of Hebrew Deuteronomy manuscripts from the Qumran caves is twenty-nine, a number that includes four excerpted texts to be discussed below. There is also one Greek Deuteronomy manuscript from Cave $7 .{ }^{1}$ This exceptionally high number of preserved manuscripts witnesses to the importance of Deuteronomy in the life and thought of the Qumran community.

1. One Deuteronomy manuscript from Wadi Murabba'at, one from Nahal Hever/Wadi Seiyal, and one from Masada were also recovered. Émile Puech has recently identified two previously unidentified Cave 4 fragments as a possible thirtieth copy of Deuteronomy from Qumran. Émile Puech, "Identification de Nouveaux Manuscrits Bibliques: Deutéronome et Proverbes dans les Débris de la Grotte 4,” RevQ 20 (2001): 121-28. 
From a text-critical viewpoint, Deuteronomy exhibits a well-preserved textual tradition. The major witnesses to the text of Deuteronomy in the Second Temple period are the proto-Masoretic text, the proto-Samaritan text, and the Septuagint text. Some of the Qumran manuscripts align with one of these major witnesses. For example, 4QDeut ${ }^{\mathrm{g}}$ does not deviate from the proto-Masoretic text in its preserved fragments, and Julie Duncan suggests that 4QDeut ${ }^{j}, 4 Q$ Deut ${ }^{\mathrm{h}}$, and 4 QDeut ${ }^{\mathrm{q}}$ witness to the Hebrew Vorlage of the Septuagint. ${ }^{2}$ The majority of Qumran manuscripts, however, are too fragmentary to place with certainty within any textual tradition.

The chief observation regarding the text of Deuteronomy in the Second Temple period is that it is expansionistic. This is not surprising given the repetitive nature of Deuteronomic prose. Duncan notes that the proto-Masoretic witness is the least expansionistic, followed by the proto-Samaritan and the Qumran manuscripts as a group. She argues that the Septuagint group is the most expansionistic. ${ }^{3}$ However, it should be noted that most of the variants preserved in the textual tradition are minor and the result of scribal error rather than deliberate intervention into the text. Deuteronomy does not exist in two variant literary traditions, as does, for example, Jeremiah.

\section{Deuteronomy as a Study Text and Basis for Liturgical Practice}

We can best observe the expansionistic tendency of the textual tradition of Deuteronomy in the excerpted texts used for liturgical or study purposes, including the phylacteries and the mezuzot. The recovery of this type of text from the Qumran caves demonstrates the importance of Deuteronomy as a study text and a basis for liturgical practice in the late Second Temple period. Four manuscripts have been identified as excerpted texts or "special-use" manuscripts: 4QDeut', 4QDeut ${ }^{\mathrm{kl}}$, 4QDeut ${ }^{\mathrm{n}}$, and 4QDeut ${ }^{\mathrm{q}}$. These manuscripts, distinguished by their small size, collect several passages from Deuteronomy, sometimes interspersed with passages from the book of Exodus. 4QDeut ${ }^{j}$ probably included (when complete) Deut 5:1-6:3; 8:5-10; 10:12-11:21; Exod 12:43-13:16; and Deut 32:1-9. 4QDeut ${ }^{\mathrm{kl}}$ contains Deut 5:28-32; 11:6-13; 32:17-18, 22-23, and 25-27. 4QDeut ${ }^{\mathrm{n}}$, an almost complete manuscript, preserves Deut 8:5-10 and 5:1-6:1, in that order. 4QDeut ${ }^{\mathrm{q}}$ appears to have contained only the Song of Moses, Deut 32:1-43. A pattern emerges for the passages preserved: three manuscripts preserve portions of chapters 5

2. Julie A. Duncan, "Deuteronomy, Book of," in The Encyclopedia of the Dead Sea Scrolls (ed. L. H. Schiffman and J. C. VanderKam; 2 vols.; New York: Oxford University Press, 2000), 1:199 3. Ibid. and 6, containing the Decalogue and the beginning of the Shema. According to $m$. Tamid 5:1, the Decalogue was recited daily in the temple along with the Shema; thus these study texts may be concerned with temple liturgy. Two manuscripts contain 8:5-10, which becomes the rabbinic basis for grace after meals; ${ }^{4}$ two manuscripts preserve portions of chapters 10-11, which also include part of the Shema; two contain parts of the Song of Moses (Deut 32:1-43); ${ }^{5}$ and one contains the passage from Exodus concerning the wearing of tefillin and the use of mezuzot. In these four manuscripts we have a collection of passages that we know from other evidence were used in worship.

In addition, 4QDeut ${ }^{\mathrm{n}}$, an expansive, harmonistic text, supplements the fourth commandment of the Decalogue, Deut 5:12-15, with the parallel passage from Exodus, 20:8-11. Thus:

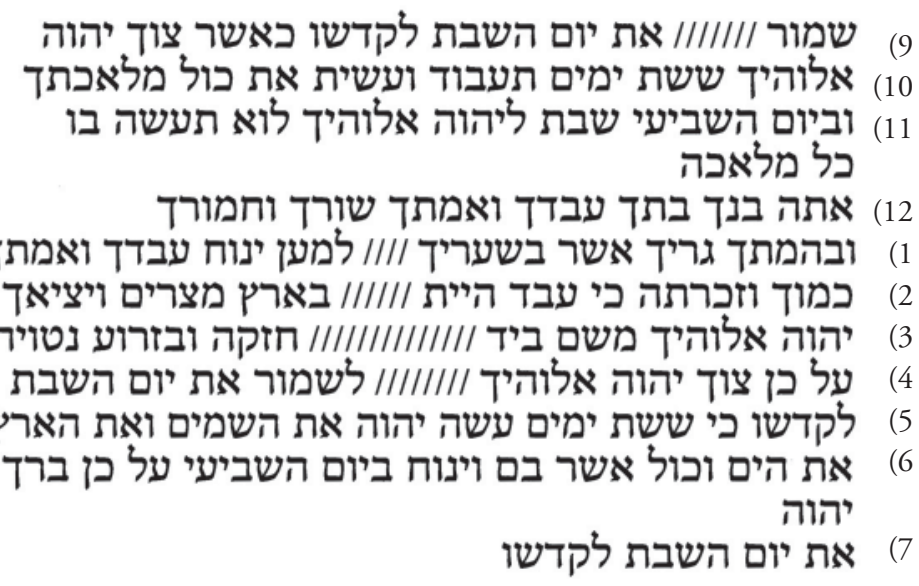

Observe the sabbath day to sanctify it, according as the LoRD your God commanded you. Six days you shall labor and do all your work, but the seventh day is a sabbath to the LORD your God. You shall not do in it any work; you, your son, your daughter, your male slave or your female slave, your ox or your ass or your beast, your sojourner who is within your gates, in order that your male slave and your female slave may rest like you. And remember that you were a slave in the land of Egypt, and the LorD your God brought you out from there with a mighty hand and an outstretched arm; therefore the LORD your God commanded you to observe the sabbath day to sanctify it. For six days the LORD made the heavens and the earth, the sea and everything which

4. Moshe Weinfeld, "Grace after Meals at Qumran," JBL 111 (1992): 427-40. Weinfeld considers 4QDeut ${ }^{\mathrm{j}}$ and $4 \mathrm{QDeut}{ }^{\mathrm{n}}$ to be liturgical texts.

5. The Song of Moses was recited in the temple on the Sabbath (b. B. Ros. Has. 31a; y. Meg. 3:6, 74b) and at the service of Ma'madot (ibid.). 
is in them, and he rested on the seventh day; therefore the Lord blessed the seventh day to sanctify it. ${ }^{6}$

From the way in which the expansion appears, we can note the deliberate work of the scribe. The word ל קרשו serves as a linking word at the beginning and end of the expansion (lines 5,7). It is likely that the scribe wished to harmonize the two Decalogue versions for his special-use copy.

With the exception of Deut 8:5-10, all the passages found in the special-use manuscripts are also found in the phylacteries and mezuzot found at Qumran. Twenty-two phylacteries and six mezuzot were recovered at Qumran. These exemplars preserve a wider range of texts than the four mandated in rabbinic practice. The four rabbinic passages are Exod 13:1-10; 13:11-16; Deut 6:4-9; and 11:1321. The phylacteries from Qumran contain all of these passages, but they contain other passages as well. According to Milik, the "maximum choice" for phylactery texts is Deut 5:1-6:9; 10:12-11:21; and Exod 12:43-13:16.7 4 QPhyl $^{\mathrm{N}}$ also contains Deut 32, so that passage must also be added to the repertoire. In addition to a wider range of pericopes included in the phylacteries, the texts of these pericopes tend to be highly expansive and often produce harmonizations. ${ }^{8}$ For example, the Decalogue in 4QPhyl G contains elements from both Deuteronomy and Exodus, although Deuteronomy appears to be the controlling text. ${ }^{9}$ Further, the Deuteronomy passages always appear first, attesting to Deuteronomy's priority, at least at Qumran. ${ }^{10}$ While some have labeled these phylacteries "sectarian" because of their differences from rabbinic practice and their scribal patterns, ${ }^{11} \mathrm{I}$ think it is more likely that the texts deemed suitable for use in phylacteries had not stabilized prior to the Bar Kokhba period. The examples from Qumran most likely represent the various Second Temple types. From the special-use manuscripts, the phylacteries, and mezuzot found at Qumran, it is clear that by this period Deuteronomy had become a central text in Judaism, and certain passages had become almost standardized for worship and study.

6. Sidnie White Crawford, "41. 4QDeut"," in Eugene Ulrich et al., Qumran Cave 4.IX: Deuteronomy, Joshua, Judges, Kings (DJD 14; Oxford: Clarendon, 1995), 124-25.

7. As quoted by Julie Duncan, "37. 4QDeut'” in Ulrich et al., DJD 14, 79.

8. Józef Tadeusz Milik, "II. Tefillin, Mezuzot et Targums (4Q128-4Q157)," in Roland de Vaux and Józef Tadeusz Milik, Qumrân Grotte 4.II (DJD 6; Oxford: Clarendon, 1977), 33-89.

9. Innocent Himbaza, "Le Décalogue du Papyrus Nash, Philon, 4Qphyl G, 8Qphyl 3 et 4Qmez A," RevQ 20 (2002): 414-16, 424-25; George Brooke, "Deuteronomy 5-6 in the Phylacteries from Qumran Cave 4," in Emanuel: Studies in the Hebrew Bible, Septuagint, and Dead Sea Scrolls in Honor of Emanuel Tov (ed. S. M. Paul et al.; VTSup 94; Leiden: Brill, 2003), 60.

10. Milik, "Tefillin, Mezuzot et Targums," 38.

11. Lawrence Schiffman, "Phylacteries and Mezuzot," in Schiffman and VanderKam, Encyclopedia of the Dead Sea Scrolls, 2:676.

\section{Harmonizations in the Scriptural Text}

We have noted that several of these liturgical or special-use manuscripts that include passages from Deuteronomy contain harmonistic or expanded texts. This phenomenon also occurs in the so-called "proto-Samaritan" group of texts, named as such because they exhibit the type of scribal intervention most fully evident in the Samaritan Pentateuch. The history of the text of the Samaritan Pentateuch has become clearer since the discoveries in the Judean Desert. It is now accepted that the Samaritan community selected as their canonical scripture a text of the Pentateuch that was in general circulation in Palestine in the Second Temple period. They then subjected this text to a thin veneer of sectarian editing. ${ }^{12}$ Once we remove this veneer of sectarian editing a text of the Pentateuch characterized by harmonizations remains. The importation of an element from one part of the text into another in order to remove contradictions from the two passages in question serves as an example of this harmonization. In the proto-Samaritan text harmonization is particularly noticeable in the importation of elements from Deut 1-9, Moses' speech on the plains of Moab reciting the wilderness history, into the parallel passages in Exodus and Numbers. Sometimes the opposite process occurred; material from Exodus or Numbers was imported into the text of Deuteronomy. For example, in Deut 2:1-8 Moses recalls that the Israelites avoided the territory of Edom, following Gods command. However, in the parallel account in Num 20, Moses sends messengers to the king of Edom asking permission to cross his territory, permission that is refused. The Samaritan Pentateuch's text of Deuteronomy inserts Moses' request from Numbers into his account after 2:7, bringing the two accounts into harmony. The presence of this change in 4 QReworked Pentateuch ${ }^{\mathrm{b}}$ (4Q364), a manuscript related to the proto-Samaritan group, demonstrates its nonsectarian nature. We observed this phenomenon of harmonization by importing elements of Exodus into the controlling Deuteronomy text in one of the Deuteronomy manuscripts classified as a liturgical or study text, 4QDeut ${ }^{\mathrm{n}}$, as well as the phylactery text $4 \mathrm{QPhyl}$ G. Thus harmonization is not a practice limited to a single stemma of biblical texts but is a more widespread phenomenon, better characterized as producing a "group."

This proto-Samaritan group is also characterized by what Emanuel Tov has termed "content editing," sometimes loosely referred to as "expansion."13

12. The two sectarian changes introduced by the Samaritans involve the addition to the Decalogue of a commandment to build an altar on Mount Gerizim and changing the formulaic statement in Deuteronomy, "the place which the Lord will choose [בחד]" to "the place which the Lord has chosen [בחד]."

13. Emanuel Tov, "Rewritten Bible Compositions and Biblical Manuscripts, with Special Attention to the Samaritan Pentateuch," DSD 5 (1998): 334-54. 
"Content editing," as used by Tov, means scribal intervention into the text in order to smooth out inconsistencies in the authoritative text. An example of this involves the fulfillment of commandments or the giving of commandments later fulfilled. A good example from Deuteronomy occurs in 4Q158, a manuscript related to the proto-Samaritan group. ${ }^{14}$ In 4Q158, which contains Deut 5:30-31, God tells Moses to command the Israelites to return to their tents (5:30). In all other known texts of Deuteronomy it is not mentioned whether or not the Israelites obeyed. 4Q158 makes clear that they did by adding the phrase "and the people returned, each man to his tent."

The fact that we have noted at least two manuscripts from the proto-Samari$\tan$ group, 4QDeut ${ }^{\mathrm{n}}$ and 4Q158, that contain scribal editorial changes not duplicated elsewhere in the tradition indicates that we are not dealing with exact copies of a certain manuscript stem but with a wider tradition of scribal intervention for harmonization and content editing. The details of this intervention may differ from witness to witness (although there is much overlap). What makes these manuscripts a group is their common scribal tradition.

This group of texts was no less authoritative in Second Temple Palestine than the shorter, more "pristine" texts of the proto-Masoretic family. This is obvious by the use of these longer texts in phylacteries, mezuzot, and liturgical/study texts. The Samaritans also selected one member of this group as the base text of their Pentateuch. So the authoritative status of these longer texts prior to the fall of the Second Temple should not be in doubt.

\section{A Reworked Pentateuch or a Rewritten Bible?}

The authoritative nature of the next group of texts I wish to examine is open to question. This group of texts, the Reworked Pentateuch, has often been placed in the category "Rewritten Bible." Others dispute that designation, arguing that the manuscripts found in the Reworked Pentateuch group are simply manuscripts of the Pentateuch and should be classified as such. ${ }^{15}$ Two of the manuscripts, 4Q364 and 4Q365, complicate the question. They appear to have been, when whole, complete manuscripts of the Torah. 4Q158, 4Q366, and 4Q367 were probably much more limited in scope, although their exact nature has yet to be determined. ${ }^{16}$

14. As first demonstrated by John Strugnell, "Notes en marge du volume V des 'Discoveries in the Judaean Desert of Jordan,"” RevQ7 (1969-70): 172.

15. E.g., Michael Segal, "4QReworked Pentateuch or 4QPentateuch?” in The Dead Sea Scrolls Fifty Years after Their Discovery, 1947-1997 (ed. L. H. Schiffman et al.; Jerusalem: Israel Exploration Society, 2000), 391-99.

16. The characterization given here differs from that in the DJD edition of 4Q364-367, where Tov and I referred to these manuscripts as copies of one composition: Emanuel Tov and
Further, these manuscripts reflect the same scribal techniques of harmonization and content editing found in the proto-Samaritan group. These manuscripts can be grouped together under the same rubric and differentiated from the proto-Samaritan group because, in addition to the scribal techniques of harmonization and content editing described above, these manuscripts exhibit a further scribal phenomenon: the addition of completely new material into the text.

Since the manuscripts of Reworked Pentateuch are not copies of a single composition, but different exemplars of the same scribal technique, we will consider each separately.

\subsection{QReworked Pentateuch ${ }^{\mathrm{b}}$}

4Q364 is a late Hasmonean manuscript that preserves portions of Genesis, Exodus, Numbers, and Deuteronomy. Fragments of Deut 1-14 are extant. As Tov and I have shown elsewhere, 4Q364's base text is a member of the proto-Samaritan group, agreeing with the Samaritan Pentateuch in two major instances of harmonization at Gen 30:36 and Deut 2:8, and not disagreeing with the Samaritan Pentateuch in any major details. ${ }^{17}$ Most of the Deuteronomy fragments of 4Q364 simply contain a running text of what we know as Deuteronomy; however, several of the fragments contain additions that illustrate the expansive scribal technique behind Reworked Pentateuch.

The best example of this technique is found in frag. 26b, e, col. ii. Line 3 of the fragment contains Deut 10:1, "And the Lord said to me, carve out for yourself two tablets of stone..." continuing on through verse 4 . Lines 1 and 2 contain text that has parallels to 9:21 and 25 (the episode of the golden calf) but is really new material inserted before 10:1. The extant text reads:

\section{[ (לעפ]ר ואשליד את : 1

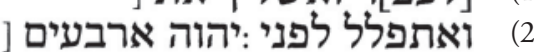

1) [to dus]t, and I threw [

2) And I prayed before the Lord forty [ ${ }^{18}$

Sidnie White, "Reworked Pentateuch," in H. Attridge et al., Qumran Cave 4. VIII: Parabiblical Texts, Part 1 (DJD 13; Oxford: Clarendon, 1994), 188-91. I no longer believe that these manuscripts are copies of the same composition; rather, they are separate exemplars of the same scribal technique.

17. Ibid., 193.

18. Ibid., 239-40. 
Although this new text does not occur in any of the known witnesses, it is an expansion of the base text that fits the context perfectly well. It has no discernible exegetical Tendenz, only repeating elements from the preceding verses, which provide a context for Moses' next foray up the mountain.

\subsection{QReworked Pentateuch}

4Q365, another late Hasmonean manuscript, preserves fragments of all five books of the Torah. Tov and I also placed 4Q365 in the proto-Samaritan group, although the evidence for $4 \mathrm{Q} 365$ is less clear-cut than it is for $4 \mathrm{Q} 364 .{ }^{19} 4 \mathrm{Q} 365$ only preserves two fragments from Deuteronomy. Still, one of those fragments, frag. 37, gives an excellent illustration of the scribal technique found in Reworked Pentateuch. The four readable lines of the fragment are as follows:

\section{[) [יכול העם המלחמה [) 3 \\ [) (4) (3) ]}

2. ]and all the warriors [

3. ]from the river Arnon, and they camped [

4. ]and they camped at $\operatorname{Ar}[$ non

5. ]water (?) until Beth (?) [20

The subject matter of this fragment relates to Moses' speech in Deut 2, which narrates the Israelites' journey through Transjordan. Verses 24 and 36 of chapter 2 mention the river Arnon. This material in frag. 37 is unparalleled elsewhere; it appears to be an expansion of the narrative in chapter 2. Again, we find no theological Tendenz in this addition. Since the manuscript is fragmentary we cannot place the passage in any more than a general context.

\subsection{QReworked Pentateuch ${ }^{\mathrm{d}}$}

4Q366, unlike 4Q364 and 365, was probably not a complete manuscript of the Pentateuch, but may have been a thematic collection of passages from the Torah. ${ }^{21}$ It preserves two fragments of Deuteronomy. One, frag. 5, contains Deut 14:13-21 with no significant variants. The other, frag. 4, col. i, has an illustra-

19. Ibid., 194.

20. Ibid., 311 .

21. Segal, “4QReworked Pentateuch or 4QPentateuch?” 395-98 tion of the Reworked Pentateuch scribal technique. Numbers 29:32-30:1 and Deut 16:13-14, two texts concerning the festival of Sukkoth, are juxtaposed.

\section{1) [וביום השביעי פרים שבעה אילם ש]נ[י]ם כבש[ים בני שנה ארבעה עשר תמימם

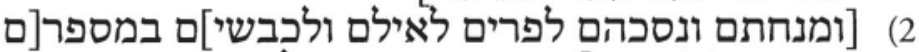

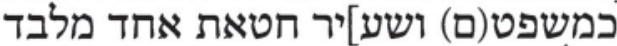

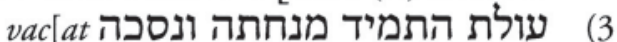

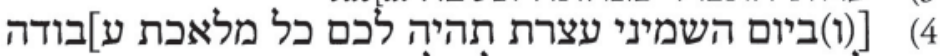

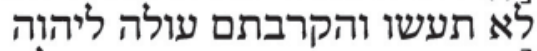

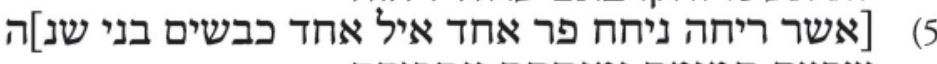

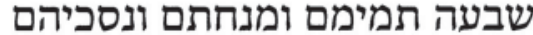

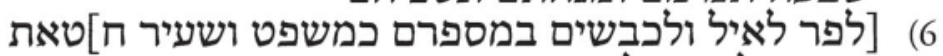

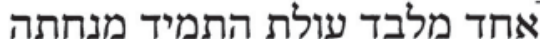

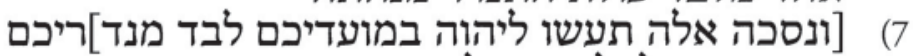

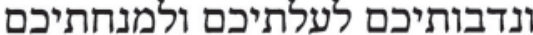

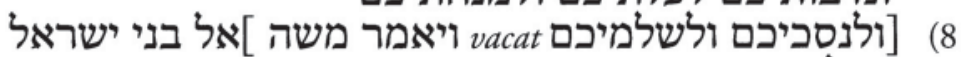 ככל אשר צוה יהוה מלכסיכם

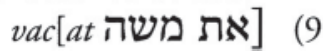

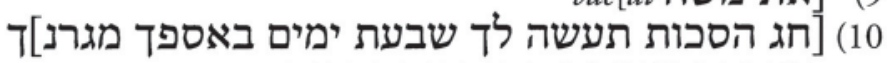 ומיקבך ושמחת בחגך אתה ובניך שת ימים}

1) [And on the seventh day; seven bulls, $t] \mathrm{w}[\mathrm{o}] \operatorname{ram}[\mathrm{s}$, fourteen male lambs without blemish,]

2) [and their grain offering and their drink offering for the bulls, for the rams and for the lambjs according to [the commandment of their] number; [and] one [male go] at for a sin offering, besides

3) [the daily burnt offering, its grain offering, and its drink offering.]

4) [(And) on the eighth day you shall have solemn assembly; you will not do [any work of la] bor. And you shall offer a burnt offering to the Lord,

5) [which is a pleasant odor: one bull, one ram,] seven y[ear old male lambs] without blemish, and their grain offering and their drink offerings

6) [for the bull, for the ram, and for the lambs according to the commandment of their number; and] one [male goat for a s] in offering, as well as the daily burnt offering and its grain offering

7) [and its drink offering. These you shall offer to the Lord at your festivals, as well as] your [votive] offerings and your freewill offerings, for your burnt offerings and for your grain offerings

8) [and for your drink offerings and for your offerings of well-being. And Moses spoke] to the children of Israel according to all which the Lord commanded

9) $[$ Moses.] 
10) [You shall keep the festival of Sukkot for seven days, when you have gathered from] your [threshing floor] and from your wine press. And you shall rejoice during your festival, you and your son ...22

Although we have placed this fragment following frag. 3, which contains Num 29:14-25, it is not clear where this fragment actually belonged in the manuscript, or what the context for the juxtaposition was (the contents of col. ii have not been identified). We seem to have a harmonization similar to those found in the proto-Samaritan group, but in a legal passage, which does not occur in the proto-Samaritan group (with the exception of the Decalogue). This example pushes the bounds of the scribal technique beyond that of the proto-Samaritan group; however, we still cannot identify a particular theological Tendenz behind the application of the scribal technique.

The question of the authoritative nature of the texts in the Reworked Pentateuch group remains unresolved. We know, of course, that the Torah, including Deuteronomy, was authoritative in the Second Temple period. According to the evidence from Qumran, we can add to that statement that various text forms of Deuteronomy existed, from short (proto-MT) to expansive (proto-Samaritan group), and even translated (LXxDeut), but that the text form did not matter for the books authority. Yet even if the form of the text did not matter for the books authority, the fact that the various forms are consistently preserved indicates that the differences were recognized by the scribes. Thus it is possible that some differentiation between the text forms was made.

If Reworked Pentateuch, especially 4Q364 and 365 as complete Torah scrolls, were simply viewed as two more copies of the Pentateuch, then we can assume they were authoritative. ${ }^{23}$ The manuscripts certainly present themselves as Torah scrolls, indicating that the scribes responsible for their production wished them to be considered authoritative. The addition of new material, which we find in Reworked Pentateuch but not in the proto-Samaritan group, may have pushed the boundaries of the text beyond the acceptable limit. If this were the case, then they may not have had the same authority as other forms of the same biblical text. ${ }^{24}$ Reworked Pentateuch

22. Tov and White, "Reworked Pentateuch," 341.

23. Eugene Ulrich, "The Qumran Scrolls and the Biblical Text," in Schiffman et al.. Dead Sea Scrolls, 57.

24. One important criterion for determining a text's authoritative status is its use by another text. It is possible, but not absolutely certain, that the additional material in 4Q365, frag. 23, regarding the festivals of wood and fresh oil, is reused in the Temple Scroll. Frag. 23's most important similarity with the Temple Scroll occurs in 11 QTemple $^{\mathrm{a}}$, col. 24, where the order of the days of the tribal offerings for wood is given: first day Levi and Judah, second day Benjamin and Joseph, third day Reuben and Simeon, fourth day Issachar and Zebulun, fifth day Gad and Asher, and takes us into a gray area with fluid boundaries between "biblical" and "rewritten." Lacking definitive evidence, the question must remain unresolved.

\section{The Use of Deuteronomy in the Temple Scroll}

Finally, I wish to examine the reuse of the book of Deuteronomy in the Temple Scroll, found in three, possibly four copies at Qumran. ${ }^{25}$ The oldest copy, 4Q524, dates to approximately 150 B.C.E. ${ }^{26}$ The last section of the Temple Scroll, cols. 5166 (according to the most complete manuscript, 11QTemple ${ }^{\mathrm{a}}$ ), is based on large chunks of Deuteronomy and is variously called Expanded Deuteronomy or the Deuteronomic Paraphrase. Embedded within this section is the Law of the King (cols. 57-59), which originally was a separate document and now functions as a long exegetical appendix to the Deuteronomic Law of the King (Deut 17:14-20).

The Deuteronomy section of the Temple Scroll is a collection of laws for life in the towns of the land, following the instructions for the ideal temple (cols. 3-13, 3047), the Festival Calendar (cols. 13-30), and a collection of purity regulations (cols. 48-51). The redactor/composer of the Deuteronomic Paraphrase takes Deuteronomy as his base text but interweaves material from other parts of the Torah, other parts of what later became the Jewish canon, and other sources, such as the Law of the King, in addition to his own exegetical comments. This produces a paraphrase of Deuteronomy, with a particular, identifiable exegetical perspective. This perspective accords in basic outline, although not always in detail, with other major documents from the Qumran collection, such as the Damascus Document.

the sixth day Dan and Naphtali. This appears to be the same order called for by 4Q365, frag. 23, which preserves Levi on the first day and Reuben and Simeon on the third day. But as I have shown elsewhere, the two texts are not identical, so it may be that they are depending on a common tradition (Sidnie White Crawford, "Three Fragments from Qumran Cave 4 and Their Relationship to the Temple Scroll," JQR 85 [1994]: 261-65). In the absence of a clear quotation of any of the additional material found in 4QReworked Pentateuch as scripture, the authoritative nature of the Reworked Pentateuch remains uncertain. However, we can say that at this point that frag. 23 of 4QReworked Pentateuch ${ }^{\mathrm{c}}$ gives evidence of a particular exegetical stance, an understanding of the proper practice of ritual law, that is also reflected in the Temple Scroll. This is the only instance of an identifiable Tendenz in the "reworked" portions of 4QReworked Pentateuch.

25. I do not believe that 4Q365a, labeled 4QTemple? in the editio princeps, is a copy of the Temple Scroll, but it contains material that may have been a source for the Temple Scroll. See Sidnie White Crawford, The Temple Scroll and Related Texts (Sheffield: Sheffield Academic Press, 2000), 15.

26. Émile Puech, "524. 4QRouleau du Temple," in idem, Qumrân Grotte 4.XVIII: Textes hébreux (4Q521-4Q528, 4Q576-4Q579) (DJD 25; Oxford: Clarendon, 1998), 85-88. 
The opening segment makes the redactor/composer s method for the reuse of Deuteronomy evident. The Deuteronomic Paraphrase begins in col. 51:11-18 (after an "open paragraph") with a discussion of just judges. In accordance with the fiction of the Temple Scroll, God speaks in the first person.

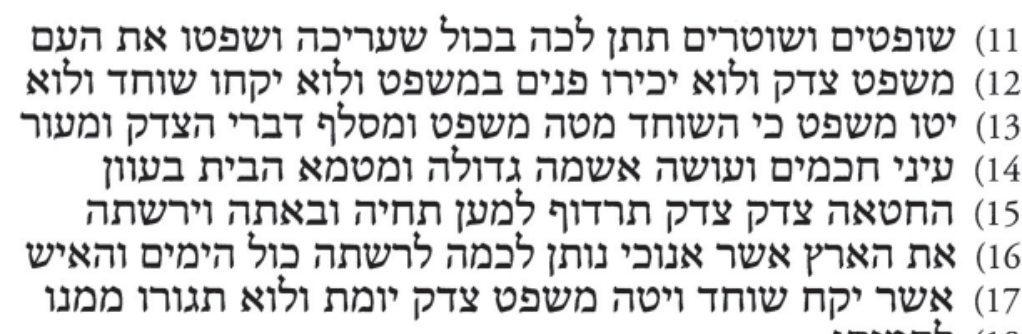

18

11) You shall appoint judges and officers in all your towns, and they shall judge the people

12) with righteous judgment. And they shall not show partiality in justice, and they shall not take a bribe, and they shall not

13) pervert justice, for the bribe perverts justice, and subverts the cause of the righteous, and blinds

14) the eyes of the wise, and causes great guilt, and defiles the house with the $\sin$ of

15) iniquity. Justice, justice you shall pursue in order that you may live and come and inherit

16) the land which I am giving you as a possession forever. And the man

17) who takes a bribe and perverts righteous justice shall be put to death; you should not be afraid of him

18) to put him to death. ${ }^{27}$

The segment begins with Deut 16:18; the redactor omits the phrase יהוה אלהיך נתן לך לשבטיך. It continues with 16:19 but weaves in part of Deut $1: 17$, converts the second-person verbs to third person, changes the order of the clauses, and adds the phrase כי השוחד מטה משפט, for the bribe perverts justice," to emphasize the point of the verse. Before the quotation from Deuteronomy continues in line 15 with צרק צרק (16:20), the redactor adds several phrases punctuating the consequences of perverting justice, the climax of which is defilement of the temple (הבית). Deuteronomy 16:20 is quoted nearly verbatim, although the text is expanded beyond the MT text and the fiction that God is speaking is maintained. Lines 17-18 draw on both Deut 1:17 and 18:22

27. Yigael Yadin, The Temple Scroll (rev. ed.; 3 vols.; Jerusalem: Israel Exploration Society, 1983), 2:227-29. ("you shall not be afraid"); like the false prophet in 18:20, the unjust judge is to die, because his actions have polluted the land. ${ }^{28}$ This punishment is not biblical but follows naturally for the redactor from his theological stance against impurity, both moral and ritual. ${ }^{29}$ Thus the point of this whole introductory section is the importance of צדק, righteousness, in the land which is Gods gift. If Deuteronomy functions as a "second law" in the Torah, both a recap of Exodus, Leviticus, and Numbers and an enlargement of their law codes to emphasize life in the land, then the Temple Scroll is a kind of "third law," meant to recap and expand Deuteronomy by the exegetical techniques and legal interpretation of the priestly circles in which the Temple Scroll originated. It is not meant to replace the Torah (including Deuteronomy) but to stand alongside it as an equally authoritative representation of Gods revelation to Moses on Sinai (illustrated throughout the scroll by God speaking in the first person). This makes the Temple Scroll an excellent exemplar of the category "Rewritten Bible."

Another example of this exegetical technique is found at the end of 11QTemplea , col. 66:8-11.

\section{8) (8י בתתה איש נערה

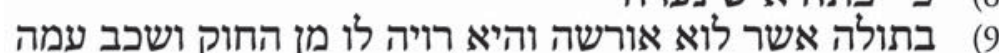

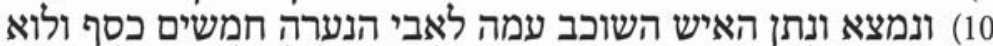 11}

8) If a man seduces a young woman

9) who is not betrothed, and she is fit for him according to the law, and he lies with her

10) and it is discovered; the man who lay with her shall give to the young woman's father fifty silver shekels, and

11) she shall be his wife, because he has violated her; he shall not be able to divorce her all his days. ${ }^{30}$

Lines 8-11 contain Deut 22:28-29. However, the redactor/composer added a clause in line 9, והיא רויה לו מן החוק, "and she is fit for him according to the law," which changes the rule according to the redactor's concern for proper, ritually pure marriages. Even in the case of the sexual seduction of a virgin, marriage within acceptable bounds is the paramount concern. A similar ruling occurs in the Damascus Document (4Q270 5 16, 4Q271 3 9-10), which warns

28. Ibid., 1:381,2:227-29.

29. Eyal Regev, "Abominated Temple and a Holy Community: The Formation of the Notions of Purity and Impurity in Qumran," DSD 10 (2003): 261.

30. Yadin, Temple Scroll, 2:298-99, with modifications. 
a father not to marry his daughter to an unfit partner. The admonition is based on exegesis of an earlier pericope in Deuteronomy, 22:9-11, and Lev 19:19, which contain the prohibitions against "mixing" (כלאים). 4QMMT B 75-82 also likens improper marital unions between priests and laity as כלים (כלאים. Thus we have a constellation of texts with the same concern for "proper" marriages, all basing their ruling on exegesis of the same Deuteronomy passage. In these texts we can observe the legal interests of the redactor/composer and his circle through the exegetical techniques he applies in his reuse of Deuteronomy. The exact relationship between the Temple Scroll, 4QMMT, and the Damascus Document is as yet undetermined, but the fact that they have the same legal concerns proves their relationship: they are products of the same movement within Judaism.

\section{Conclusion}

I have presented several examples of manuscripts from the Qumran collection that testify to the importance and popularity of the book of Deuteronomy in the Second Temple period. Deuteronomy was an authoritative text in and of itself, an important book in the creation of texts for study purposes and/or liturgical use, and was used as a base text in the exegetical creation of Rewritten Bible works with claims to their own authority. Deuteronomy may be termed the "second law" but clearly had attained first place in Second Temple Judaism.

Published in Reading the Present in the Qumran Library: The Perception of the Contemporary by Means of Scriptural Interpretations, edited by Kristin De Troyer and Armin Lange, with the assistance of Katie M. Goetz and Susan Bond. Society of Biblical Literature Symposium Series \#30, Christopher R. Matthews, General Editor. Leiden \& Boston: Brill, 2005. Copyright 2005 by the Society of Biblical Literature. Used by permission. 